$\xi=$

\title{
The Attributes of Knowledge Worker as Prime Movers in Public Organizations
}

\author{
*Em Roosehaziram Mohd Rahim ${ }^{1}$, Saiful Farik Mat Yatin ${ }^{1}$, Muhammad Aidid Adil Zainal ${ }^{1}$, Khairul Mizan Taib ${ }^{1}$, \\ Bunyamin Mohamed ${ }^{2}$ \\ ${ }^{I}$ Faculty of Information Management, Universiti Teknologi MARA (UiTM) Selangor, Malaysia \\ ${ }^{2}$ Multimedia Consultant of Biro Tatanegara (BTN), Putrajaya, Malaysia \\ * Corresponding author: *Em Roosehaziram Mohd Rahim: Faculty of Information Management, Universiti Teknologi MARA (UiTM) \\ Selangor, Malaysia \\ Email: annrahimms@gmail.com
}

\begin{abstract}
Civics Department in public sector of Malaysia has a major responsibility in ensuring that Malaysians instilled with the spirit of patriotism and moral values and aspirations of the nation for preparing Malaysia to achieve developed nation by 2020 . With the goal to achieve its vision as a Leader of National Patriotism, a special task force known as Tenaga Penggerak (TP) has been created. This task force acts as a driver to achieve the mission by delivering excellence patriotism program through education, training, awareness and strategic partnerships. TP also have the objective to improve the knowledge and understanding of patriotism and statehood, government policies, current issues, and appreciation of moral values. TP also can be known as knowledge worker in this department based on its responsibilities and main critical success factor of every planned activities and to achieve the objective. This paper proposes positive approach to maintain the quality knowledge worker in Civics Department in instilling patriotism and statehood of Malaysian citizen.
\end{abstract}

Keywords: Tenaga Penggerak, knowledge worker, patriotism driver, civics department, civics and patriotic in public sector

\section{Introduction}

Nowadays, the need for knowledge workers has affected the organization and people. People need to change from view of life that they still can survive as long as they work hard, onto the new view that they need to be knowledgeable and work smart to continue life. While, organizations need to ensure that their employees have sufficient knowledge by ensuring that the knowledge is always channeled, it is not hidden.

Knowledge is always embodied in a person; carried by a person; created, augmented, or improved by a person; applied by a person; taught and passed on by a person; used or misused by a person. The shift to the knowledge society therefore puts the person in the center [1-2].

As mentioned by Peter Drucker [3], Laili Hashim and Khairul Mizan Taib [4] that knowledge is being applied to knowledge itself. It is now fast becoming the one factor of production, sidelining both capital and labour.

While, Mládková and Nový [5] record that knowledge workers are growing group of employees in both advanced and emerging economies. The major tool and resource of their work is knowledge. Due to its tacit dimension, knowledge is of intangible character. Knowledge work is done in heads of knowledge workers, it is nonlinear, difficult to capture. Even though knowledge workers are usually responsible professionals, wrong motivation can negatively influence their performance.

Laili b. Hashim and Khairul Mizan Taib4 mentioned that the emergence of the knowledge economy (K-economy) has a big impact on the nature of business. They were grouped the workers into four levels of skills which are as follows:
Professional workers (skill level A): occupations for which a university degree (bachelor"s, master"s, or postgraduate level) is required

- $\quad$ Specialized technical workers (skill level B): occupations requiring two- three years of post-secondary education at a community college or technology institute; two - four years of apprenticeship training; or three to four years of secondary school and more than two years of on-the-job training, specialized training courses, or specific work experience

- Intermediate workers (skill level $\mathrm{C}$ ): jobs requiring one to four years of secondary school education or up to two years of on-the-job training, specialized training courses, or specific work experience

- Unskilled workers (skill level D): up to two years of secondary.

Such employees are known as knowledge workers in that they "have high degrees of expertise, education, or experience, and the primary purpose of their jobs involves the creation, distribution or application of knowledge" [2,6].

Knowledge workers will also continue to decline if they are not properly monitored and managed. Thus, in order to maintain knowledge workers in the organization, various ways are needed. In this situation, a special management is required.

Knowledge workers literally own the means of production and carry knowledge, information, and "know-how" skills in their heads [7]. Thus, it shows that a very proper management is needed to retain knowledge workers.

If there is no proper management, it is not impossible that it will have an impact on the organization. For organizations that are dependent on financial gain, it may cause reducing sales and pur- 
chases because of productions reduced or the services are unsatisfactory of customers.

Meanwhile, profit-based organizations to service to clients such as government organizations will likely provide negative imagery such as the slowdown of services and thwart government objectives and policies.

Retaining employees whose knowledge has high competitive value is becoming a critical and well-recognized challenge. [5, 8-12]. Educate the workers and deliver good motivation also is one of the ways to manage these knowledge workers.

Davidson and Voss [13] stated that computers are fast, accurate but dumb; on the other hand, human are slow and sloppy but smart! Therefore Laili Hashim and Khairul Mizan Taib4 remind, it is very crucial to focus on the most critical element that is human which include the education and training for the knowledge worker.

Robbins [14], Mládková and Nový5 defines motivation as the willingness to exert high levels of effort toward organizational goals, conditioned by the effort's ability to satisfy some individual need.

This means that in order to achieve organizational target objectives, knowledge workers are needed and need to be managed as best as possible so that these valuable assets are not shift and exit of the organization.

\section{Roles of Tenaga Penggerak (TP)}

Tenaga Penggerak is an individual which is appointed to carry out the activities under the National Transformation Training (LTN) either as a speaker, religious interpreter, facilitator and part-time trainer. They are the one who had interpreter, facilitator and parttime trainer. They are the one who had knowledge and expertise which is related to any activities given to them to be handled.

They also are the one who had contributed to the successful implementation of the National Transformation Training. They are the pulse of the department during handling the activities. This is because most of the activities of the National Transformation Program (PTN) is operated by the beginning of the passage brainstorming, sermon, Peningkatan Keilmuan Penjanaan Kesedaran (PKPK)/Group Discussion (PDK) and Physical Motion Activity [15].

Therefore, the Civics Department must always be make sure that the selected and entrusted TP to carry out activities of National Transformation Training (LTN) is composed of individuals who are knowledgeable, experienced and always try to increase the knowledge in their respective fields.

Knowledge divided by two (2) which is explicit; the part of knowledge formally expressed through code, differs code based on character and sharing knowledge via ICT. While, tacit is partly and fully subconscious and develop through learning (practical) [5].

Remarkably, TP of Civics Department must dominate both of that knowledge; explicit and tacit. Due to these specialty, individuals who have been selected as TP are reliable and trusted to help the sector and nation to achieve the related goals and objectives.

TP in Civics Department was not the person who are permanently work as the department's staff. They have their own professional job but when they are selected or why they are selected, they have to know or already know a lots of thing or in other word knowledgeable. Especially about the government policies and general matters such as religion, patriotism, nationalism and current issues Manual of Tenaga Penggerak Section [15 stated that diversity of knowledgeable TP are required because they have to:

- control activities (talks/lectures, PKPK, recreation) in National Transformation Program Training (PLTN) according to target groups.

- deliver detailed and factual information about current issues and government policies. They are one of the best medium to explain the issues that are not clear or explicit accusations. answer questions raised by participants regarding current issues or policies of the government that need to be clarified and explained at that time. Answering any participants' questions/concerns during the PLTN in any topics such as religious, race, community and etc. is one of the roles of TP. Therefore, they are always combined in each activity or course with a multitude of fields and expertise according to target groups.

to achieve government need which is to generate as much as the quality generations in various aspects. In each activities, they should applying the values of patriotism and moral values among participants because producing as many as civilized generation and as nation's quality asset is also an objective of the Civics Department was established.

\section{Tenaga Penggerak (TP) Management}

TP has an important role to ensure the success of the activities of the National Transformation Training (LTN). Failure to select the appropriate and skilled TP, certainly affect the quality of National Transformation Training (LTN) as a whole. Thus the process of nomination, selection and appointment of utmost importance.

Accurate and appropriate nominations by the sector's headquarter and state will facilitate the adjustment process for the selection and appointment of TP by Tenaga Penggerak Section, Transformation and Patriotic Division.

The appointed TP should be enhanced of their level of skills to control activities and knowledge that are always relevant to current issues.

Hopefully by providing this guidance, all the matters related to the TP can be implemented in an efficient and orderly manner.

Table 1: Guidance for Tenaga Penggerak Management

\begin{tabular}{|c|c|}
\hline $\begin{array}{l}\text { Tenaga } \\
\text { Penggerak (TP) }\end{array}$ & $\begin{array}{l}\text { Individuals which is appointed to carry out the } \\
\text { activities under the National Transformation } \\
\text { Training (LTN) either as a speaker, religious } \\
\text { interpreter, facilitator and part-time trainer. }\end{array}$ \\
\hline $\begin{array}{l}\text { Secretariat of } \\
\text { Tenaga } \\
\text { Penggerak } \\
\text { Management }\end{array}$ & $\begin{array}{l}\text { Secretariat of the speakers, religious interpreters, } \\
\text { facilitators and part-time trainers operated by } \\
\text { Tenaga Penggerak Section, Transformation and } \\
\text { Patriotic Division. The function of the Secretariat } \\
\text { is to coordinate the process of selecting, } \\
\text { appointing and terminating the service of Tenaga } \\
\text { Penggerak. }\end{array}$ \\
\hline $\begin{array}{l}\text { Tenaga } \\
\text { Penggerak } \\
\text { Coordinator } \\
\text { (PPTP) }\end{array}$ & $\begin{array}{l}\text { The officer appointed in each of the training } \\
\text { division/the state will be responsible for the } \\
\text { coordination arrangement and monitoring of } \\
\text { Tenaga Penggerak which was registered in the } \\
\text { training division/the state respectively. }\end{array}$ \\
\hline $\begin{array}{l}\text { Tenaga } \\
\text { Penggerak } \\
\text { Assistant } \\
\text { Coordination } \\
\text { Officer (PPPTP) }\end{array}$ & $\begin{array}{l}\text { The staff appointed to assist Tenaga Penggerak } \\
\text { Coordinator (PPTP) in each of the training } \\
\text { division/the state. }\end{array}$ \\
\hline $\begin{array}{l}\text { Sahabat } \\
\text { Building } \\
\text { Program (PMS) }\end{array}$ & $\begin{array}{l}\text { Special programs to choose Tenaga Penggerak. } \\
\text { The program aims to assess the abilities, skills, } \\
\text { appearance and suitability to be a Tenaga } \\
\text { Penggerak of department. }\end{array}$ \\
\hline Trainer & $\begin{array}{l}\text { Individuals who had served in the uniformed body } \\
\text { (ATM, PDRM, JPAM) which is appointed by } \\
\text { department. }\end{array}$ \\
\hline
\end{tabular}

\section{Recruitment Planning of Tenaga Penggerak (TP)}

Selection of TP of Civics Department must go through several phases. They are not appointed as TP simply just fill out the form or through courses such as regular participants.

They have to go through phases of screening in terms of academic requirements, then attended several special courses of general knowledge, which also tested in terms of discipline, selfconfidence, understanding of the issues and government policy, nationalism, patriotism, ability to answer questions as well as control of the situation and how to handle specific groups

There is special division in Civics Department to manage TP which is known as Tenaga Penggerak Section, Transformation and Patriotic Division. All the recruitment planning for speaker, 
facilitator, religious interpreter and part-time trainer which is includes in TP group will be implemented by this division.

The division has set several criteria for the selection of a person as TP of department. They are chosen based on the following criteria:

\section{Speaker/Religious Interpreter}

Those who are willing to be a speaker or/and religious interpreter of Civics Department should have presentation skill which is they can attract the audience according to the target groups in term of the way they perform their presentation with the high level of knowledge in given topic and how they answered the asked questions.

\section{Facilitator}

Facilitators were selected after specific screenings based on their communication skill. Communicating become an important criteria to be a facilitator in Civics Department. They also should have an ability to be a good listener because the listening skill is important to them to understanding their participants. Beside that, they also need to have the ability to understanding of any issues and must have a good level of knowledge. In addition, Civics Department facilitators need to have a great personality in terms of appearance, commitment to the success of the assignment and the level of self-discipline is very high.

\section{Program Coordinator}

After the vetting have been done, the Program Coordinator for each courses attended by potential facilitator, will write comments or notes about those candidates to be sent to Tenaga Penggerak Section, Transformation and Patriotic Division.

\section{Trainer}

Civics Department do not recruit the regular trainer to serve as trainer in National Transformation Training (LTN). Usually, the selected trainer was chosen not just because of their academic level only but also their experiences in the uniformed body such as an army and some of them have been involved as a commando.

They also should have communication skill to interact with participants according to the target groups. They also must have another skill which is to handle physical activity.

Beside that, the physical fitness is important for the trainer. They must always be alert and more energetic than the participants. In addition, having the high level discipline and commitment also important in handling the activity. They also should show the good appearance style along the course.

The planning of the recruitment is not just about the criteria above. The Tenaga Penggerak Section, Transformation and Patriotic Division should be make sure the number of TP are enough based on the needs of implementation of the Annual National Transformation Training (LTN), for a program/seminar is set by the management and the necessity according to the training division/the state.

The selection of TP also needs to be through several phases of proposed and agreed upon by high-levels of management which is Director-General, Deputy of Director-General, Director of Division and State Director. The names of proposed candidates shall be sent to Tenaga Penggerak Section, Transformation and Patriotic Division. Details of proposed candidates shall contain the following:

i. Academic Qualifications

a) Bachelor degree and above (speaker / facilitator)

b) Diploma / certificate equivalent (religious interpreter only)

c) SPM or Sergeant (trainer only)

ii. Attended National Transformation Training (if present)

iii. Involvement in the Civics Department programs

iv. Involvement in social activities and NGOs

v. Health level

\section{vi. Recent job and experiences}

\section{Problems and Challenges}

Laili Hashim and Khairul Mizan Taib ${ }^{4}$ stated that some failures of program are due to differences in background, insufficient infrastructure and facilities and also inadequate model.

\section{Differences in background}

Perception and acceptance vary depending on the background TP has different backgrounds of educations and experiences, for example Lecturers, General Managers of organizations, business people, and high rank military. It possibility will create disagreements or difference in opinion and only mutually allow their own opinions to be very high. This situation will have the effect of carrying out activities smoothly.

\section{Infrastructure and facilities}

The Civics Department only has no more than 20 camps throughout Malaysia to implement regulated programs. Since there are many needs and demands of public and private organizations, educational institutions and associations to undergo courses / activities from this department, the existing facilities are insufficient to runs all the demands of programs.

\section{Inadequate model}

Civics Department still do not have any models to make it as a reference. For this time being, there are no other organizations or country that has this kind of modus operandi. Civics Department is the only one or in other word the pioneer of this type of knowledge worker management. This will make the department forced to use try and error solutions in order to achieve the objectives.

\section{De-motivation Factors}

Based to Veber [16], Mládková and Nový ${ }^{5}$ mentioned that typical factors that work as negative motivation are wrong motivation tools, wrong managerial practices, missing managerial activities, dissilusion, conflict between what managers says and what he does, lack of information, subjectivism, secretiveness, rumors, unclear order and tasks, unclear evaluation of work, bad working morals and unethical behavior of managers.

The only selected person can be a TP of the Civics Department. This means that they are indeed knowledgeable drivers to the department. But, some of them were not fully utilized by the organization which is only the same people or "teams" that were used for most of the courses and activities. Besides that, the low moral quality of some officers such as biased and negative feelings towards TP; prejudice, despised, misunderstood, are the contribution factors of this problems and challenges. It shows that Veber ${ }^{16}$ statement about the typical factors that work as negative motivation is correct.

\section{Suggested Approaches}

\section{Retention}

Nelson and $\mathrm{McCann}^{2}$ discussed that companies have generally adopted two types of retention or responses to combat employee turnover: proactive defensive measures that make the work environment more appealing, including increases in salaries and benefits, recognition programs, employee training, team initiatives, improving internal communications, etc., and reactive retaliatory approaches that increase the costs associated with leaving, including aggressive enforcement of non-compete clauses, threat of litigation, etc $[12,17]$.

When discussing about TP, it means that the discussion is refering to human factor. Humans are the object where they have feelings and it can be change just in a second. In order to make sure the retention of TP in Civics Department which is as one of 
main factor to achieve the the objective and functions, there is several things should be considered and implemented.

In a survey, the retention of TP in Civics Department can be achieved if a relationship between TP themselves, and relationship between TP and officers and staff always be keep in good level for all the times. In order to make their relationship always in good, it can be achieved by improving internal communication between them. At the same time, it show that team orientation should be synchronized between each other who are in the same teams.

A culture that values interpersonal relationships and collaboration, a team orientation, and respect for people has been shown to result in longer tenure [18].

Eventhough TP already have their own career outside the Civics Department, the consolatory gift in kind as payment or allowances can be a factor of the retention of this knowledge worker in the department. So, the rate of the gift should be appropriate with the skills, knowledge and experiences they have and have been contributed.

Training in term of Training-of-Trainer (TOT), discussion or convention should be done frequently, so that the TP will always updated their knowledge. Frequently training will update them with the latest information and knowledge about the module. While, discussion and convention will avoid any prejudice to the any issues and better understand the real scenario and situation in order to better explain to target groups. It also will make them feel appreciated by the department itself.

Besides that, sharing knowledge between TP especially from the seniors of TP will make other TP especially the junior will always have additional knowledge. The management of the Civics Department and TP should have this team initiative so that the department will always no lacking of knowledgeable TP. Sutherland [19], on the other hand, found that job satisfaction and organizational commitment did not predict knowledge worker employment duration, but other important factors did include high autonomy, career development opportunities, performance related rewards, and challenging work assignments. The recognition programs which have done today should be continued and added in the future so that they will be feeling much appreciated as all the knowledge and experience delivered to participants organized by the department is not easy to get.

\section{Motivation Factors}

Mládková and Nový ${ }^{5}$ suggest that motivation factor is one of the factor for the success of an activities.

Studies show that TP will feel satisfied and happy when the goal of the activities or courses is reached. This is cause of by the factor of operation officer's leadership. One of the factors of achievement in objective will be reached if the operation officer or known as Facilitator Chief can give clear instruction of the program's objective and the tools to be used. Thereby, TP can performs the tasks smoothly and give the full effort to meet the objective.

Physically satisfaction such as facilities, foods and tools also can give a motivation to the TP. Besides that, mentally satisfaction by the officer in-charge, participants or clients can affect the motivation of this knowledge worker.

The officer's in-charge for any Civics Department's programs which need to use the TP skills and knowledge should know to distribute the appropriate tasks or module to the suitable TP. For example, for outdoor activities should be handled by the TP of physical activities.

It is important to motivate these knowledge workers by given them the freedom of will because they themselves have lots of experiences and knowledge about the programs and activities. It is means that, if they have positive requirement in implement the activities, it should be encouraged as long as the objective achieve.

\section{Conclusion}

The management of Tenaga Penggerak; the specialty knowledge workers, should know that these types of workers are highly committed to their profession, driven by accomplishment, sensitive about their freedom, sensitive on micro management and sensitive on how their manager treats them. So that, it is very encourage able that the management also keep sensitive to all the mentioned above.

To ensure the quality of services in Civics Department in term of achieving the objective of the activities and programs and to make sure they reached of the department's vision and the government's needs as stated in this studies, all parties in this department; Tenaga Penggerak, management and staff, need to work together because by having the only knowledgeable Tenaga Penggerak as a driving force without cooperation between all levels of employees will not provide efficient results.

\section{Acknowledgement}

This paper was partially funded by:

1. Conference Support Fund, Institute of Graduate Studies (IPSis, UiTM)

2. Academic Development Trust Fund (TAPA), Faculty of Information Management, UiTM

3. Yayasan Minda Fund

\section{References}

[1] Drucker PF. The Essential Drucker. New York: Harper Collins. 2001.

[2] Nelson K, McCann JE. Designing for Knowledge Worker Retention \& Organization Performance. Journal of Management and Marketing Research. 2010;3:1-18 http://www.aabri.com/manuscripts/09272.pdf

[3] Drucker, P. What is Knowledge Worker? 2004. Available at: http://.navcentre.borgess.com/LworkerManual/ePages/front_page/ $\mathrm{kw}$ def.html

[4] Laili Hashim, Khairul Mizan Taib Training and Development for Knowledge Workers - Malaysian Scene. International Journal of Business, Humanities and Technology. 2012;2:138-147. http://www.ijbhtnet.com/journals/Vol2No2March2012/18.pdf

[5] Mládková LZ, Nový J. Motivation and Knowledge Worker. Procedia - Social and Behavioral Sciences. 2015;207:768-776. http://www.sciencedirect.com/science/article/pii/S187704281505 2969

[6] Davenport TH. Thinking for a Living: How to Get Better Performance and Results from Knowledge Workers. Boston: Harvard Business School Press. 2005.

[7] Lagace M. The Key to Managing Stars? Think Team. HBS Working Knowledge. 2007. May 14. Retrieved May 29, 2008 from http://hbswk.hbs.edu/item/5617.html

[8] DeLong DW. Lost Knowledge: Confronting the Threat of an Aging Workforce. New York: Oxford University Press. 2004

[9] Frank FD, Finnegan RP, Taylor CR. The Race for Talent: Retaining and Engaging Workers in the 21st. Century. Human Resource Planning. 2004;27(3):12-25.

[10] Jamrog J. The Perfect Storm: The Future of Retention and Engagement. Human Resource Planning. 2004;27(3): 26-33.

[11] Ready DA, Conger JA. How to Fill the Talent Gap: Global Companies Face a Perfect Storm when it Comes to Finding the Employees they Need. The Wall Street Journal Online. 2007 September 15; R1. Retrieved May 29, 2008 from http://online.wsj.com/public/article_print/SB11884169542871251 1.html.

[12] Somaya D, Williamson IO. Rethinking the 'War for Talent'. MIT Sloan Management Review 2008;49:4.

[13] Davidson C, Voss P. Knowledge Management: An Introduction to Creating Competitive Advantage from Intellectual Capital. New Delhi: Vision Books. 2003.

[14] Robbins S. Organizational Behaviour (6th. ed.). Englewood Cliffs. Prentice Hall. 1993.

[15] Manual of Tenaga Penggerak Section, Transformation and Patriotic Division. 2016. 
[16] Veber J. et al., Management, základy, moderní manažerské prístupy, výkonnost a prosperita. Management Press. Praha. 2009. ISBN 978-80-7261-200-0.

[17] Wagar TH, Rondeau KV. Retaining Employees in Small and Medium-Sized Firms: Examining the Link with Human Resource Management. The Journal of Applied Management and Entrepreneurship. 2006;11(2):3-16.

[18] Sheridan JE. Organizational Culture and Employee Retention. Academy of Management Journal. 1992;35(5):1036-1056.

[19] Sutherland MM. Factors Affecting the Retention of Knowledge Workers. Unpublished Doctoral Dissertation, Rand Afrikaans University. 2004. Retrieved May 15, 2008, from http://etd.rau.ac.za/theses/available/etd-11172004-

131718/restricted/ 